\title{
Teknik Pematahan Dormansi Secara Fisik dan Kimia terhadap Viabilitas Benih Aren (Arenga pinnata Merr.)
}

\author{
Dormancy Breaking Technique by Physical and Chemical Means on Viabitity of Palm \\ Seed (Arenga pinnata Merr.) \\ Ismaturrahmi $^{1}$, Agam Ihsan Hereri ${ }^{1 *}$, Hasanuddin ${ }^{1}$ \\ ${ }^{1}$ Program Studi Agroteknologi, Fakultas Pertanian, Universitas Syiah Kuala
}

\begin{abstract}
Abstrak. Penelitian ini bertujuan untuk mengetahui pengaruh teknik pematahan dormansi secara fisik dan kimia, serta nyata tidaknya interaksi antara pematahan dormansi secara fisik dengan pematahan dormansi secara kimia terhadap viabilitas benih aren. Penelitian ini dilaksanakan di Laboratorium Ilmu dan teknologi Benih, Fakultas Pertanian, Universitas Syiah Kuala, Darussalam, Banda Aceh, dari bulan juli sampai November 2017. Penelitian ini menggunakan Rancangan Acak Lengkap (RAL) Pola Faktorial 4 x 4 dengan 3 ulangan. Penelitian ini menggunakan 2 faktor yaitu: pematahan dormansi secara fisik $(\mathrm{S})$, meliputi : $\left(\mathrm{S}_{0}\right)=$ Tanpa perlakuan fisik, $\left(\mathrm{S}_{1}\right)=$ Digosok dengan kertas amplas, $\left(\mathrm{S}_{2}\right)=$ Digores dengan cutter sepanjang punggung benih, dan $\left(\mathrm{S}_{3}\right)=$ Menghilangkan selaput gabus pada hilum, dan pematahan dormansi secara kimia $(\mathrm{K})$, meliputi: $\left(\mathrm{K}_{0}\right)=$ Konsentrasi $0 \% \mathrm{KNO}_{3},\left(\mathrm{~K}_{1}\right)=$ Konsentrasi $0,3 \% \mathrm{KNO}_{3},\left(\mathrm{~K}_{2}\right)=$ Konsentrasi $0,5 \% \mathrm{KNO}_{3},\left(\mathrm{~K}_{3}\right)=$ Konsentrasi $0,7 \% \mathrm{KNO}_{3}$. Hasil penelitian yang telah dilakukan, dapat diambil kesimpulan bahwa : Kombinasi perlakuan secara fisik yang digores dengan cutter $\left(\mathrm{S}_{2}\right)$ dengan konsentrasi $\mathrm{KNO}_{3} \quad 0,5 \%\left(\mathrm{~K}_{2}\right)$ merupakan kombinasi perlakuan terbaik untuk pematahan dormanis pada benih aren.
\end{abstract}

Kata kunci: Aren, $\mathrm{KNO}_{3}$, Perlakuan secara fisik.

\begin{abstract}
This research aims to know the effect of physics and chemical dormancy breaking technique, and significant or not the interaction between physical dormancy breaking with chemical dormancy breaking on the viability of the palm seeds. This research was conducted in Science and Seed Technology Laboratory, Faculty of Agriculture, Syiah Kuala University, Darussalam, Banda Aceh, from July to November 2017. This research used Factorial Completely Randomize Design with 4 x 4 repeated 3 times. This research uses 2 factors, namely: physical dormancy breaking $(\mathrm{S})$, including: $\left(\mathrm{S}_{0}\right)=$ Without physical treatment, $\left(\mathrm{S}_{1}\right)=$ Rubbed with sandpaper, $\left(\mathrm{S}_{2}\right)=$ scratched with cutter along the back of seed, and $\left(\mathrm{S}_{3}\right)=$ Eliminate the cork membrane on the hylum, and chemical dormancy breaking $(\mathrm{K})$, namely: $\left(\mathrm{K}_{0}\right)=$ Concentration $0 \% \mathrm{KNO}$, $\left(\mathrm{K}_{1}\right)=$ Concentration $0.3 \% \mathrm{KNO}$, $\left(\mathrm{K}_{2}\right)=$ Concentration $0.5 \% \mathrm{KNO},\left(\mathrm{K}_{3}\right)=$ Concentration $0.7 \% \mathrm{KNO}_{3}$. The results of research that has been done, it can be concluded that: The combination of physical treatment scratched with cutter $\left(\mathrm{S}_{2}\right)$ with $\mathrm{KNO}_{3}$ concentration of $0.5 \%\left(\mathrm{~K}_{2}\right)$ is the best treatment combination for dormanic breaking of palm seeds.
\end{abstract}

Key words: Palm, $\mathrm{KNO}_{3}$, Physical treatment

\section{PENDAHULUAN}

Tanaman aren juga merupakan tanaman perkebunan yang berpotensial tinggi untuk dikembangkan di Indonesia. Dewasa ini budidaya tanaman aren masih dilakukan secara tradisional, teknik budidaya yang masih sederhana, bahkan bahan tanam (bibit) yang digunakan oleh petani berasal dari bibit sembarang (liar). Sistim budidaya tanaman aren yang dilakukan oleh petani masih mengandalkan tanaman yang tumbuh secara alami (Maliangkay, 2007).

Benih aren memerlukan waktu relatif lama untuk berkecambah karena benih aren memiliki struktur kulit yang tebal dan keras. Pada kondisi alami benih aren baru mampu berkecambah 5-6 bulan setelah semai (Mashud et al., 1989). Untuk mempercepat perkecambahan benih aren dapat dilakukan usaha pematahan dormansi baik itu secara fisik dan kimia. Pematahan dormansi secara fisik yaitu dengan pelukaan benih didekat embrio dan digosok dengan kertas pasir, sedangkan pematahan dormansi secara kimia yaitu dengan melakukan perendaman benih dalam larutan seperti $\mathrm{KNO}_{3}, \mathrm{HCl}, \mathrm{H}_{2} \mathrm{SO}_{4}$ dan hormon Giberelin $\left(\mathrm{GA}_{3}\right)$. 
Dormansi benih adalah ketidakmampuan benih untuk berkecambah pada kondisi lingkungan yang optimum. Penyebab dari dormansi pada benih terjadi karena ada bagian benih yang impermeabel, seperti kulit benih yang keras atau embrio yang belum masak. Beberapa studi perlakuan benih untuk pematahan dormansi benih aren baik itu secara fisik maupun kimia belum didapatkan hasil yang memuaskan. Benih aren yang diberi perlakuan fisik yaitu dengan mengikis kulit benih atau skarifikasi benih dengan menggunakan kertas amplas dengan kecepatan berkecambahnya yaitu 49 - 57 hari dan daya berkecambahnya 50 $55 \%$ (Saleh, 2002).

Hasil penelitian tersebut diatas sesuai dengan yang dinyatakan oleh Gardner et al., (1991) yang menyatakan bahwa asam kuat sangat efektif untuk mematahkan dormansi pada biji yang memiliki struktur dan kulit biji yang keras, sehingga kulit benih menjadi lunak serta air dan oksigen dapat berimbibisi kedalam benih.

Perlakuan benih aren secara fisik dapat dikombinasikan dengan perlakuan secara kimia agar perkecambahan menjadi lebih cepat dengan daya berkecambah yang tinggi. Kombinasi yang sering digunakan dalam pematahan dormansi benih aren yaitu perlakuan secara fisik yang dikombinasikan dengan cara kimia melalui perendaman benih dalam larutan $\mathrm{KNO}_{3}$ (Saleh, 2004). Tujuan dari perlakuan ini yaitu untuk melunakkan kulit benih. Saleh (2003) dalam hasil penelitiannya menyatakan bahwa benih aren yang direndam dalam larutan $\mathrm{KNO}_{3}$ dengan konsentrasi $0,5 \%$ dengan lama perendaman 36 jam dapat meningkatkan kecepatan berkecambah 37 hari dengan daya berkecambah hingga $85 \%$.

Hartawan (2016), menyatakan bahwa kecepatan berkecambah benih akan meningkat apabila benih direndam dalam larutan $\mathrm{KNO}_{3}$, hal ini diduga karena adanya perbaikanperbaikan terhadap faktor-faktor yang menunjang proses perkecambahan seperti aktifnya beberapa enzim setelah terjadinya penyerapan air. $\mathrm{KNO}_{3}$ dapat berperan dalam mendorong reaksi-reaksi kimia yang mengarah ke perkecambahan dan merangsang aktivitas enzim. $\mathrm{KNO}_{3}$ diduga juga dapat meningkatkan efektivitas giberelin dalam perkecambahan.

Tujuan penelitian ini adalah untuk mengetahui pengaruh teknik pematahan dormansi secara fisik dan kimia, serta nyata tidaknya interaksi antara pematahan dormansi secara fisik dengan pematahan dormansi secara kimia terhadap viabilitas benih aren.

\section{METODE PENELITIAN}

Penelitian ini dilaksanakan pada bulan Juli sampai November 2017 di Laboratorium Ilmu dan teknologi Benih, Fakultas Pertanian, Universitas Syiah Kuala, Darussalam, Banda Aceh, dengan menggunakan rancangan acak lengkap pola factorial 4 x 4 dengan 3 ulangan. Ada 2 faktor yang diteliti yaitu pematahan dormansi secara fisik yang terdiri dari 4 taraf yaitu tanpa perlakuan fisik, digosok dengan kertas amplas, digores dengan cutter sepanjang punggung benih dan menghilangkan selaput gabus pada hilum, dan pematahan dormansi secara kimia $\left(\mathrm{KNO}_{3}\right)$ yang terdiri dari 4 taraf yaitu $0 \%, 0,3 \%, 0,5 \%$ dan $0,7 \%$. Secara keseluruhan terdapat 16 kombinasi perlakuan.

\section{Parameter yang diamati pada penelitian ini yaitu :}

1. Potensi Tumbuh (Sutopo, 2004)

$$
\text { PT }(\%)=\frac{\text { Jumlah benih yang menunjukkan gejala tumbuh }}{\text { Jumlah benih yang ditanam }} \times 100 \%
$$

2. Daya Berkecambah (Sutopo, 2004)

$$
\text { DB }(\%)=\frac{\Sigma \text { KN hitungan I }+\Sigma \text { KN hitungan II }}{\text { Jumlah benih yang ditanam }} \times 100 \%
$$


3. Nilai Penundaan Perkecambahan (Halimursyadah et al, 2015)

$$
\text { NPP }(\%)=\frac{\Sigma \text { benih yang belum berkecambah }}{\Sigma \text { Jumlah benih yang ditanam }} \times 100 \%
$$

4. Kecepatan Tumbuh (Sutopo, 2004)

$$
\mathrm{K}_{\mathrm{CT}}(\% / \text { etmal })=\frac{N 1}{D 1}+\frac{N 2}{D 2}+\frac{N 3}{D 3}+\cdots \cdot+\frac{N n}{D n}
$$

5. Indeks Vigor (Halimursyadah et al, 2015)

$$
\text { IV }(\%)=\frac{\Sigma \text { KN Hitungan I }}{\Sigma \text { Benih yang ditanam }} \times 100 \%
$$

6. Waktu yang dibutuhkan untuk mencapai $50 \%$ perkecambahan relatif $\left(\mathrm{T}_{50}\right)$ (Halimursyadah et al, 2015)

$$
\mathrm{T}_{50}(\text { hari })=\mathrm{ti}+\left(\frac{n 50-n i}{n j-n i}\right)(\mathrm{tj}-\mathrm{ti})
$$

7. Keserempakan Tumbuh (Halimursyadah et al, 2015)

$$
\mathrm{K}_{\mathrm{st}}=\frac{\Sigma \text { Kecambah normal kuat }(\text { hari ke-99) }}{\Sigma \text { Benih yang ditanam }} \mathrm{X} 100 \%
$$

\section{HASIL DAN PEMBAHASAN}

\section{Interaksi Antara Perlakuan Secara Fisik dan Perlakuan Secara Kimia $\left(\mathrm{KNO}_{3}\right)$ Terhadap Viabilitas Benih Aren}

\section{Potensi Tumbuh}

\begin{tabular}{|c|c|c|c|c|}
\hline \multirow{2}{*}{ Perlakuan Secara Fisik } & \multicolumn{4}{|c|}{ Perlakuan Secara Kimia $\left(\mathrm{KNO}_{3}\right)$} \\
\hline & $0 \%(\mathrm{~K} 0)$ & $0,3 \%(\mathrm{~K} 1)$ & $0,5 \%(\mathrm{~K} 2)$ & $0,7 \%(\mathrm{~K} 3)$ \\
\hline Tanpa perlakuan fisik (S0) & $\begin{array}{c}5,21 \mathrm{~b} \\
(26,67)\end{array}$ & $\begin{array}{c}7,22 \mathrm{c} \\
(51,67)\end{array}$ & $\begin{array}{c}8,09 \mathrm{c} \\
(65,00)\end{array}$ & $\begin{array}{c}8,16 \mathrm{c} \\
(66,67)\end{array}$ \\
\hline Digosok dengan kertas amplas (S1) & $\begin{array}{c}4,66 \mathrm{~b} \\
(21,67)\end{array}$ & $\begin{array}{l}0,71 \mathrm{a} \\
(0,00)\end{array}$ & $\begin{array}{l}1,25 \mathrm{a} \\
(1,67)\end{array}$ & $\begin{array}{l}2,10 \mathrm{a} \\
(5,00)\end{array}$ \\
\hline Digores dengan cutter (S2) & $\begin{array}{c}8,19 \mathrm{c} \\
(66,67)\end{array}$ & $\begin{array}{c}8,49 \mathrm{c} \\
(71,67)\end{array}$ & $\begin{array}{l}8,69 \mathrm{~cd} \\
(75,00)\end{array}$ & $\begin{array}{c}8,96 \mathrm{~d} \\
(80,00)\end{array}$ \\
\hline Menghilangkan selaput gabus (S3) & $\begin{array}{c}4,10 \mathrm{~b} \\
(16,67)\end{array}$ & $\begin{array}{c}5,35 \mathrm{~b} \\
(28,33)\end{array}$ & $\begin{array}{c}4,50 \mathrm{~b} \\
(20,00)\end{array}$ & $\begin{array}{l}4,50 \mathrm{~b} \\
(20,00)\end{array}$ \\
\hline BNJ 0,05 & \multicolumn{4}{|c|}{1.71} \\
\hline
\end{tabular}

Rata-rata nilai potensi tumbuh akibat interaksi antara perlakuan secara fisik dan perlakuan secara kimia $\left(\mathrm{KNO}_{3}\right)$ setelah di uji dengan BNJ 0,05 dapat dilihat pada Tabel 1.

Tabel 1. Rata-rata nilai potensi tumbuh akibat interaksi antara perlakuan secara fisik dan perlakuan secara kimia $\left(\mathrm{KNO}_{3}\right)$

Berdasarkan Tabel 1 menunjukkan bahwa potensi tumbuh yang lebih baik dijumpai pada perlakuan digores dengan cutter (S2) pada konsentrasi $\mathrm{KNO}_{3} 0,7 \%$ (K3) yang berbeda tidak nyata dengan perlakuan digores dengan cutter (S2) pada konsentrasi $\mathrm{KNO}_{3} 0,5 \%(\mathrm{~K} 2)$. Namun berbeda nyata dengan perlakuan lainnya. 


\section{Daya Berkecambah (\%)}

Rata-rata nilai daya berkecambah akibat interaksi antara perlakuan secara fisik dan perlakuan secara kimia $\left(\mathrm{KNO}_{3}\right)$ setelah di uji dengan $\mathrm{BNJ}$ 0,05 dapat dilihat pada Tabel 2.

Tabel 2. Rata-rata nilai daya berkecambah akibat interaksi antara perlakuan secara fisik dan perlakuan secara kimia $\left(\mathrm{KNO}_{3}\right)$

\begin{tabular}{lcccc}
\hline \multirow{2}{*}{\multicolumn{1}{c}{ Perlakuan Secara Fisik }} & \multicolumn{4}{c}{ Perlakuan Secara Kimia $\left(\mathrm{KNO}_{3}\right)$} \\
\cline { 2 - 5 } & $0 \%(\mathrm{~K} 0)$ & $0,3 \%(\mathrm{~K} 1)$ & $0,5 \%(\mathrm{~K} 2)$ & $0,7 \%$ \\
& $5,21 \mathrm{c}$ & $7,22 \mathrm{~d}$ & $7,98 \mathrm{de}$ & $8,16 \mathrm{de}$ \\
Tanpa perlakuan fisik (S0) & $(26,67)$ & $(51,67)$ & $(63,33)$ & $(66,67)$ \\
& $4,66 \mathrm{c}$ & $0,71 \mathrm{a}$ & $0,71 \mathrm{a}$ & $0,71 \mathrm{a}$ \\
Digosok dengan kertas amplas (S1) & $(21,67)$ & $(0,00)$ & $(0,00)$ & $(0,00)$ \\
& $8,19 \mathrm{de}$ & $8,49 \mathrm{de}$ & $8,69 \mathrm{de}$ & $8,96 \mathrm{e}$ \\
Digores dengan cutter (S2) & $(66,67)$ & $(71,67)$ & $(75,00)$ & $(80,00)$ \\
& $4,10 \mathrm{c}$ & $5,35 \mathrm{c}$ & $2,40 \mathrm{~b}$ & $0,71 \mathrm{a}$ \\
Menghilangkan selaput gabus (S3) & $(16,67)$ & $(28,33)$ & $(6,67)$ & $(0,00)$ \\
\hline
\end{tabular}

$$
\text { BNJ 0,05 }
$$

1,59

Keterangan : Angka yang diikuti oleh huruf yang sama pada baris yang sama berbeda tidak nyata pada taraf 5\% $\left(\mathrm{Uji}_{\mathrm{BNJ}}{ }_{0,05}\right) ;($ ): data asli, data ditransformasi menggunakan $\sqrt{\mathrm{x}}+0,5$

Berdasarkan Tabel 2 menunjukkan bahwa daya berkecambah yang lebih baik dijumpai pada perlakuan digores dengan cutter (S2) pada konsentrasi $\mathrm{KNO}_{3}$ 0,7\% (K3) yang berbeda tidak nyata dengan perlakuan digores dengan cutter (S2) pada konsentrasi $\mathrm{KNO}_{3} 0 \%(\mathrm{~K} 0)$, $0,3 \%(\mathrm{~K} 1)$ dan $0,5 \%(\mathrm{~K} 2)$, juga berbeda tidak nyata dengan tanpa perlakuan fisik (S0) pada konsentrasi $\mathrm{KNO}_{3} 0,5 \%(\mathrm{~K} 2)$ dan $0,7 \%(\mathrm{~K} 3)$. Namun berbeda nyata dengan perlakuan lainnya.

\section{Nilai Penundaan Perkecambahan}

Rata-rata nilai penundaan perkecambahan akibat interaksi antara perlakuan secara fisik dan perlakuan secara kimia $\left(\mathrm{KNO}_{3}\right)$ setelah di uji dengan $\mathrm{BNJ}$ 0,05 dapat dilihat pada Tabel 3.

Tabel 3. Rata-rata nilai penundaan perkecambahan akibat interaksi antara perlakuan secara fisik dan perlakuan secara kimia $\left(\mathrm{KNO}_{3}\right)$

\begin{tabular}{|c|c|c|c|c|}
\hline \multirow[b]{2}{*}{ Perlakuan Secara Fisik } & \multicolumn{4}{|c|}{ Perlakuan Secara Kimia (KNO3) } \\
\hline & $\begin{array}{l}0 \% \\
(\mathrm{~K} 0)\end{array}$ & $0,3 \%(\mathrm{~K} 1)$ & $\begin{array}{l}0,5 \% \\
(\mathrm{~K} 2)\end{array}$ & $0,7 \%(\mathrm{~K} 3)$ \\
\hline Tanpa perlakuan fisik (S0) & $\begin{array}{c}8,59 \mathrm{~g} \\
(73,33)\end{array}$ & $\begin{array}{c}6,87 \text { efg } \\
(46,67)\end{array}$ & $\begin{array}{c}6,48 \text { def } \\
(41,67)\end{array}$ & $\begin{array}{c}5,79 \text { def } \\
(33,33)\end{array}$ \\
\hline Digosok dengan kertas amplas (S1) & $\begin{array}{c}4,45 \text { bcd } \\
(20,00)\end{array}$ & $\begin{array}{l}3,70 \mathrm{bc} \\
(13,33)\end{array}$ & $\begin{array}{c}2,64 \mathrm{abc} \\
(6,67)\end{array}$ & $\begin{array}{c}2,63 \mathrm{ab} \\
(8,33)\end{array}$ \\
\hline Digores dengan cutter (S2) & $\begin{array}{c}5,65 \mathrm{cdef} \\
(31,67)\end{array}$ & $\begin{array}{c}5,35 \text { cdef } \\
(28,33)\end{array}$ & $\begin{array}{c}5,65 \text { cdef } \\
(31,67)\end{array}$ & $\begin{array}{l}4,31 \mathrm{bc} \\
(18,33)\end{array}$ \\
\hline Menghilangkan selaput gabus (S3) & $\begin{array}{c}4,48 \text { cde } \\
(23,33)\end{array}$ & $\begin{array}{c}4,66 \mathrm{bcd} \\
(21,67)\end{array}$ & $\begin{array}{l}3,70 \mathrm{bc} \\
(13,33)\end{array}$ & $\begin{array}{l}1,25 \mathrm{a} \\
(1,67)\end{array}$ \\
\hline BNJ 0,05 & \multicolumn{4}{|c|}{2,05} \\
\hline
\end{tabular}


Tabel 3 menunujukkan bahwa nilai penundaan perkecambahan yang terbaik dijumpai pada tanpa perlakuan fisik (S0) pada konsentrasi $\mathrm{KNO}_{3} 0 \%(\mathrm{~K} 0)$. yang berbeda tidak nyata dengan tanpa perlakuan fisik (S0) dengan konsentrasi $\mathrm{KNO}_{3} 0,3 \%(\mathrm{~K} 1)$, namun berbeda nyata dengan perlakuan lainnya.

\section{Kecepatan Tumbuh}

Rata-rata nilai kecepatan tumbuh akibat interaksi antara perlakuan secara fisik dan perlakuan secara kimia $\left(\mathrm{KNO}_{3}\right)$ setelah di uji dengan $\mathrm{BNJ}{ }_{0,05}$ dapat dilihat pada Tabel 4.

Tabel 4. Rata-rata nilai kecepatan tumbuh akibat interaksi antara perlakuan secara fisik dan perlakuan secara kimia $\left(\mathrm{KNO}_{3}\right)$

\begin{tabular}{lcccc}
\hline \multirow{2}{*}{ Perlakuan Secara Fisik } & \multicolumn{4}{c}{ Perlakuan Secara Kimia (KNO3) } \\
\cline { 2 - 5 } & $0 \%(\mathrm{~K} 0)$ & $0,3 \%(\mathrm{~K} 1)$ & $0,5 \%(\mathrm{~K} 2)$ & $0,7 \%$ \\
& $0,91 \mathrm{~d}$ & $1,11 \mathrm{e}$ & $1,17 \mathrm{e}$ & $1,17 \mathrm{e}$ \\
\hline \multirow{2}{*}{ Tanpa perlakuan fisik (S0) } & $(0,32)$ & $(0,73)$ & $(0,88)$ & $(0,86)$ \\
& $0,89 \mathrm{~cd}$ & $0,71 \mathrm{a}$ & $0,72 \mathrm{ab}$ & $0,73 \mathrm{ab}$ \\
Digosok dengan kertas amplas (S1) & $(0,30)$ & $(0,00)$ & $(0,01)$ & $(0,03)$ \\
& $1,19 \mathrm{ef}$ & $1,18 \mathrm{e}$ & $1,29 \mathrm{fg}$ & $1,30 \mathrm{~g}$ \\
Digores dengan cutter (S2) & $(0,92)$ & $(0,90)$ & $(1,16)$ & $(1,20)$ \\
& $0,86 \mathrm{~cd}$ & $0,88 \mathrm{~cd}$ & $0,81 \mathrm{bc}$ & $0,81 \mathrm{bc}$ \\
Menghilangkan selaput gabus (S3) & $(0,24)$ & $(0,28)$ & $(0,15)$ & $(0,15)$ \\
\hline BNJ 0,05 & \multicolumn{4}{c}{0,09} \\
\hline Keterangan : Angka yang diikuti oleh huruf yang sama pada baris yang sama berbeda tidak nyata pada taraf 5\% \\
\multicolumn{1}{c}{ (Uji BNJ ${ }_{0,05}$ ); (): data asli, data ditransformasi menggunakan $\sqrt{\mathrm{x}+0,5}$}
\end{tabular}

Tabel 4 menunjukkan bahwa pertumbuhan yang lebih cepat dijumpai pada perlakuan digores dengan cutter (S2) pada konsentrasi $\mathrm{KNO}_{3} \quad 0,7 \%$ (K3). yang berbeda tidak nyata dengan perlakuan digores dengan cutter (S2) pada konsentrasi $\mathrm{KNO}_{3} 0,5 \%$ (K2), namun berbeda nyata dengan perlakuan lainnya.

\section{Indeks Vigor}

Rata-rata nilai indeks vigor akibat interaksi antara perlakuan secara fisik dan perlakuan secara kimia $\left(\mathrm{KNO}_{3}\right)$ setelah di uji dengan $\mathrm{BNJ}{ }_{0,05}$ dapat dilihat pada Tabel 5.

Tabel 5. Rata-rata nilai indeks vigor akibat interaksi antara perlakuan secara fisik dan perlakuan secara kimia $\left(\mathrm{KNO}_{3}\right)$

\begin{tabular}{lcccc}
\hline \multirow{2}{*}{ Perlakuan Secara Fisik } & \multicolumn{4}{c}{ Perlakuan Secara Kimia (KNO3) } \\
\cline { 2 - 5 } & $0 \%(\mathrm{~K} 0)$ & $0,3 \%(\mathrm{~K} 1)$ & $0,5 \%(\mathrm{~K} 2)$ & $0,7 \%(\mathrm{~K} 3)$ \\
\hline \multirow{2}{*}{ Tanpa perlakuan fisik (S0) } & $2,35 \mathrm{~b}$ & $4,13 \mathrm{c}$ & $4,53 \mathrm{c}$ & $4,53 \mathrm{c}$ \\
& $(5,00)$ & $(16,67)$ & $(20,00)$ & $(20,00)$ \\
Digosok dengan kertas amplas (S1) & $2,64 \mathrm{~b}$ & $0,71 \mathrm{a}$ & $0,71 \mathrm{a}$ & $0,71 \mathrm{a}$ \\
& $(6,67)$ & $(0,00)$ & $(0,00)$ & $(0,00)$ \\
Digores dengan cutter (S2) & $4,70 \mathrm{~cd}$ & $4,13 \mathrm{c}$ & $5,67 \mathrm{de}$ & $5,93 \mathrm{e}$ \\
& $(21,67)$ & $(16,67)$ & $(31,67)$ & $(35,00)$ \\
Menghilangkan selaput gabus (S3) & $2,35 \mathrm{~b}$ & $2,35 \mathrm{~b}$ & $1,25 \mathrm{a}$ & $0,71 \mathrm{a}$ \\
& $(5,00)$ & $(5,00)$ & $(1,67)$ & $(0,00)$ \\
\hline BNJ 0,05 & \multicolumn{5}{c}{0,99} \\
\hline
\end{tabular}

Keterangan : Angka yang diikuti oleh huruf yang sama pada baris yang sama berbeda tidak nyata pada taraf $5 \%$ (Uji BNJ 0,05$) ;($ ): data asli, data ditransformasi menggunakan $\sqrt{x}+0,5$ 
Tabel 5 menunjukkan nilai indeks vigor yang lebih baik dijumpai pada perlakuan digores dengan cutter (S2) pada konsentrasi $\mathrm{KNO}_{3} 0,7 \%$ (K3) yang tidak berbeda nyata dengan perlakuan digores dengan cutter (S2) pada konsentrasi $\mathrm{KNO}_{3} 0,5 \%(\mathrm{~K} 2)$, namun berbeda nyata terhadap perlakuan lainnya.

\section{Waktu yang dibutuhkan untuk mencapai $50 \%$ perkecambahan total $\left(\mathbf{T}_{50}\right)$}

Rata-rata $\mathrm{T}_{50}$ akibat interaksi antara perlakuan secara fisik dan perlakuan secara kimia $\left(\mathrm{KNO}_{3}\right)$ setelah di uji dengan $\mathrm{BNJ}{ }_{0,05}$ dapat dilihat pada Tabel 6.

Tabel 6. Rata-rata $\mathrm{T}_{50}$ akibat interaksi antara perlakuan secara fisik dan perlakuan secara kimia $\left(\mathrm{KNO}_{3}\right)$

\begin{tabular}{lcccc}
\hline \multirow{2}{*}{ Perlakuan Secara Fisik } & \multicolumn{4}{c}{ Perlakuan Secara Kimia (KNO3) } \\
\cline { 2 - 5 } & $0 \%(\mathrm{~K} 0)$ & $0,3 \%$ & $0,5 \%$ & $0,7 \%$ \\
$(\mathrm{~K} 1)$ & $(\mathrm{K} 2)$ & $(\mathrm{K} 3)$ \\
\hline \multirow{2}{*}{ Tanpa perlakuan fisik (S0) } & $9,36 \mathrm{bc}$ & $8,75 \mathrm{bc}$ & $9,00 \mathrm{bc}$ & $9,18 \mathrm{bc}$ \\
\multirow{2}{*}{ Digosok dengan kertas amplas (S1) } & $(8,95 \mathrm{bc}$ & $0,71 \mathrm{a}$ & $4,29 \mathrm{ab}$ & $7,88 \mathrm{bc}$ \\
& $(79,77)$ & $(0,00)$ & $(43,67)$ & $(87,33)$ \\
Digores dengan cutter (S2) & $8,84 \mathrm{bc}$ & $9,32 \mathrm{bc}$ & $8,43 \mathrm{bc}$ & $8,55 \mathrm{bc}$ \\
\multirow{2}{*}{ Menghilangkan selaput gabus (S3) } & $(77,57)$ & $(86,37)$ & $(70,57)$ & $(72,60)$ \\
& $8,56 \mathrm{bc}$ & $10,35 \mathrm{c}$ & $10,97 \mathrm{c}$ & $11,47 \mathrm{c}$ \\
& $(73,03)$ & $(106,57)$ & $(120,23)$ & $(131,00)$ \\
\hline
\end{tabular}

BNJ 0,05

6,04

Keterangan : Angka yang diikuti oleh huruf yang sama pada baris yang sama berbeda tidak nyata pada taraf 5\% $\left(\mathrm{Uji}_{\mathrm{BNJ}} \mathrm{B}, 05\right) ;($ ): data asli, data ditransformasi menggunakan $\sqrt{\mathrm{x}}+0,5$

Tabel 6 menunjukkan bahwa nilai $\mathrm{T}_{50}$ yang lebih tinggi dijumpai pada perlakuan menghilangkan selaput gabus (S3) pada konsentrasi $\mathrm{KNO}_{3} 7 \%$ (K3) yang berbeda nyata dengan perlakuan digosok dengan kertas amplas (S1) pada konsentrasi $\mathrm{KNO}_{3} 0,3 \%(\mathrm{~K} 1)$ dan $\mathrm{KNO}_{3} 0,5 \%(\mathrm{~K} 2)$, namun berbeda tidak nyata pada perlakuan lainnya.

\section{Keserempakan Tumbuh}

Rata-rata keserempakan tumbuh akibat interaksi antara perlakuan secara fisik dan perlakuan secara kimia $\left(\mathrm{KNO}_{3}\right)$ setelah di uji dengan $\mathrm{BNJ}{ }_{0,05}$ dapat dilihat pada Tabel 7.

Tabel 7. Rata-rata keserempakan tumbuh akibat interaksi antara perlakuan secara fisik dan perlakuan secara kimia $\left(\mathrm{KNO}_{3}\right)$

\begin{tabular}{lcccc}
\hline \multirow{2}{*}{ Perlakuan Secara Fisik } & \multicolumn{4}{c}{ Perlakuan Secara Kimia (KNO3) } \\
\cline { 2 - 5 } & $\begin{array}{c}0 \% \\
(\mathrm{~K} 0)\end{array}$ & $\begin{array}{c}0,3 \% \\
(\mathrm{~K} 1)\end{array}$ & $0,5 \%(\mathrm{~K} 2)$ & $\begin{array}{c}0,7 \% \\
(\mathrm{~K} 3)\end{array}$ \\
\hline \multirow{2}{*}{ Tanpa perlakuan fisik (S0) } & $4,13 \mathrm{a}$ & $6,75 \mathrm{de}$ & $7,11 \mathrm{def}$ & $6,49 \mathrm{~d}$ \\
& $(16,67)$ & $(45,00)$ & $(50,00)$ & $(41,67)$ \\
Digosok dengan kertas amplas (S1) & $4,00 \mathrm{c}$ & $0,71 \mathrm{a}$ & $0,71 \mathrm{a}$ & $0,71 \mathrm{a}$ \\
& $(16,67)$ & $(0,00)$ & $(0,00)$ & $(0,00)$ \\
Digores dengan cutter (S2) & $7,56 \mathrm{def}$ & $6,74 \mathrm{de}$ & $8,30 \mathrm{ef}$ & $8,46 \mathrm{f}$ \\
\multirow{2}{*}{ Menghilangkan selaput gabus (S3) } & $(56,67)$ & $(45,00)$ & $(68,33)$ & $(71,67)$ \\
& $3,90 \mathrm{c}$ & $2,94 \mathrm{bc}$ & $1,55 \mathrm{ab}$ & $0,71 \mathrm{a}$ \\
& $(15,00)$ & $(8,33)$ & $(3,33)$ & $(0,00)$ \\
\hline BNJ 0,05 & \multicolumn{5}{c}{1,63} \\
\hline Keterangan : Angka yang diikuti oleh huruf yang sama pada baris yang sama berbeda tidak nyata pada taraf 5\% \\
\multicolumn{1}{c}{ (Uji BNJ $_{0,05}$ ); ( ): data asli, data ditransformasi menggunakan $\sqrt{\mathrm{x}+0,5}$}
\end{tabular}


Tabel 7 menunjukkan bahwa nilai keserempakan tumbuh yang lebih baik dijumpai pada perlakuan digores dengan cutter (S2) pada konsentrasi $\mathrm{KNO}_{3} 0,7 \%$ (K3) yang berbeda tidak nyata dengan perlakuan digores dengan cutter (S2) pada konsentrasi $\mathrm{KNO}_{3} 0,5 \%(\mathrm{~K} 2)$, dan konsentrasi $\mathrm{KNO}_{3} 0 \%$ (K0), dan tanpa perlakuan fisik (S0) dengannkonsentrasi $\mathrm{KNO}_{3}$ $0,5 \%$ (K2). Namun berbeda nyata dengan perlakuan lainnya.

\section{Pembahasan}

\section{Interaksi antara perlakuan secara fisik dan perlakuan secara kimia $\left(\mathrm{KNO}_{3}\right)$ terhadap viabilitas benih aren}

Berdasarkan hasil penelitian pengaruh interaksi antara perlakuan secara fisik dan perlakuan secara kimia $\left(\mathrm{KNO}_{3}\right)$ yang diamati berdasarkan tolak ukur viabilitas benih seperti potensi tumbuh, daya berkecambah, nilai penundaan perkecambahan, indeks vigor, kecepatan tumbuh, waktu yang dibutuhkan untuk mencapai $50 \%$ dari perkecambahan total $\left(\mathrm{T}_{50}\right)$ dan keserempakan tumbuh, memberikan hasil yang berbeda dari keempat taraf perlakuan fisik yang diamati terhadap konsentrasi $\mathrm{KNO}_{3}$ yang dicobakan. Hasil penelitian ini menunjukkan bahwa perlakuan digores dengan cutter (S2) dengan konsentrasi $\mathrm{KNO}_{3} 0,5 \%$ (K2) dengan kecepatan berkecambahnya yaitu 70 hari dengan daya berkecambah $75 \%$ merupakan kombinasi perlakuan terbaik berdasarkan tolok ukur viabilitas benih.

Sementara pada perlakuan digosok dengan menggunakan kertas amplas (S1) dan perlakuan menghilangkan selaput gabus pada hilum (S3) yang direndam dalam larutan $\mathrm{KNO}_{3}$ selama 36 jam mengakibatkan benih menjadi busuk, sehingga banyak benih yang tidak dapat berkecambah pada kombinasi perlakuan tersebut. Hal ini disebabkan karena benih mengalami pembusukan pada embrio dengan munculnya lendir dan jamur yang mengakibatkan benih itu mati. Hal ini juga dapat disebabkan oleh tingginya konsentrasi $\mathrm{KNO}_{3}$ yang diberikan sehingga menyebabkan kulit benih aren menjadi busuk.

Larutan $\mathrm{KNO}_{3}$ adalah senyawa asam yang umum digunakan untuk melakukan pematahan dormansi pada benih dan dapat menstimulir perkecambahan, namun apabila dikombinasikan dengan perlakuan secara fisik dapat menyebabkan kerusakan pada benih. Dari hasil tersebut dapat disimpulkan bahwa perendaman dalam konsentrasi tinggi maupun rendah tidak mempengaruhi nilai penundaan perkecambahan benih aren pada perlakuan digosok dengan kertas amplas (S1) dan menghilangkan selaput gabus pada hilum (S3) pada setiap konsentrasi $\mathrm{KNO}_{3}$, melainkan menyebabkan terjadinya keracunan terhadap benih tersebut. Hal ini diduga karena struktur ketebalan kulit benih yang berbeda-beda. Sesuai dengan yang dinyatakan Schmidt (2002) bahwa lamanya waktu perendaman benih dalam larutan asam ada 2 hal yang harus diperhatikan, yaitu : kulit benih atau perikarp dapat diretakkan dan embrio tidak terkena oleh larutan asam.

Dari pernyataan diatas dapat dilihat bahwa pada penelitian ini benih-benih yang diberi perlakuan fisik digosok dengan kertas amplas (S1) dan menghilangkan selaput gabus pada hilum (S3) pada setiap taraf konsentrasi $\mathrm{KNO}_{3}$ mengalami pembusukan karena embrio benih tersebut sudah terkena larutan asam.

\section{KESIMPULAN DAN SARAN}

Dari hasil penelitian yang telah dilakukan, dapat diambil kesimpulan bahwa : Perlakuan secara fisik yang lebih baik dijumpai pada perlakuan digores dengan cutter. Perlakuan secara kimia yang lebih baik dijumpai pada konsentrasi $\mathrm{KNO}_{3} 0,5 \%$. Interaksi perlakuan yang lebih baik dijumpa pada kombinasi perlakuan secara fisik digores dengan cutter dengan konsentrasi $\mathrm{KNO}_{3} 0,5 \%$. 


\section{DAFTAR PUSTAKA}

Gardner, F. P., R. B. Pearce dan R. L. Mitchell. 1991. Fisiologi Tumbuhan Budidaya. Penerjemah Herawati Susilo. UI Press. Jakarta.

Halimursyadah., Syamsuddin., Sabaruddin., A. I. Hereri., S. Imran., Hasanuddin., Syafruddin., T. Kurniawan. 2015. Teknologi dan industri benih. Universitas Syiah Kuala. Darussalam. Banda Aceh.

Hartawan., R. 2016. Skarifikasi dan $\mathrm{KNO}_{3}$ mematahkan dormansi serta meningkatkan viabilitas dan vigor benih aren (Arrnga pinnata Merr.) Jurnal Media Pertanian. 1 (1) : $1-10$.

Maliangkay, R, B. 2007. Teknik budidaya dan rehabilitasi tanaman aren. Buletin Palma No.33, 67-77.

Mashud N. R. Rahman dan R. B. Maliangkay. 1989. Pengaruh berbagai perlakuan fisik dan kimia terhadap perkecambahan dan pertumbuhan bibit aren (Arenga pinnata(Wurmb.) Merr). Jurnal penelitian kelapa 4 (1) : 27 - 37.

Saleh, M. S. 2002. Perlakuan fisik dan kalium nitrat untuk mempercepat perkecambahan benih aren dan pengaruhnya terhadap pertumbuhan kecambah. Jurnal Agroland 9 (4) : 32-330.

Saleh, M. S. 2003. Peningkatan kecepatan berkecambah benih aren yang diberi perlakuan fisik dan lama perendaman $\mathrm{KNO}_{3}$. Agroland (Suplemen) : 52-57.

Saleh, M. S. 2004. Pematahan dormansi benih aren secara fisik pada berbagai lama ekstraksi buah. Agrosains 6 (2) : 78-83.

Schmidt, L. I. 2002. A Tutorial on Principal Components Analysis.

Sutopo, L. 2004. Teknologi Benih. edisi Revisi. Cetakan ke-6.PT Raja Grafindo. Jakarta. 